\title{
GYAKORLATI OKTATÁS TÁMOGATÁSA
}

\author{
Drótos Dániel \\ tanszéki mérnök, Miskolci Egyetem, Automatizálási és Infokommunikációs Intézet \\ 3515 Miskolc, Miskolc-Egyetemváros, e-mail: iitddani@uni-miskolc.hu
}

\begin{abstract}
Absztrakt
Az egyetemi oktatásban is jelentös szerepe van a gyakorlati oktatásnak. A müszaki képzések tantárgyainak gyakorlatain a hallgatók méréseket végeznek, tervezési feladatokat oldanak meg. A munkájukat dokumentálniuk kell mérési jegyzökönyvek, tervezési dokumentáció, vagy szoftverek formájában. A Miskolci Egyetem Automatizálási és Infokommunikációs Intézetében kifejlesztett egyedi informatikai rendszer a gyakorlati oktatás minden fázisát támogatja, beleértve a feladatok rendszerezését, a beosztások elkészitését, a feladat kiadást, a dokumentumok összegyüjtését és értékelését.
\end{abstract}

Kulcsszavak: oktatás, gyakorlat, informatikai rendszer, feladatbeadás, értékelés

\begin{abstract}
Practical education also plays a significant role in university education. During the exercises of the subjects of the technical trainings, the students perform measurements and solve planning tasks. They must document their work in the form of measurement reports, design documentation, or software. The unique information system developed at the Institute of Automation and Infocommunication of the University of Miskolc supports all phases of practical education, including the systematization of tasks, the preparation of assignments, the submission of tasks, the collection and evaluation of documents.
\end{abstract}

Keywords: education, practice, information system, task submission, evaluation

\section{Bevezetés}

Az egyetemi képzésekben is fontos szerepe van a gyakorlati oktatásnak. A müszaki képzések tantárgyai esetében különösen nagy a fontossága a gyakorlatok során elvégzett mérési, tervezési feladatoknak. A Covid-19 járvány kialakulása miatt azonban a hallgatók gyakorlati munkájának megszervezése nehezebbé vált.

Szükségessé vált a gyakorlatok megszervezése oly módon, hogy a hallgatók személyes jelenléte csökkenthető legyen. Ezt támogatják egyes távoktatási módszerek, mint például a mérőhelyek müszereinek távoli elérése, távvezérlése interneten keresztül [1], vagy a szimulációs szoftverek használata [2].

Emellett csökkenthető a hallgatókkal való személyes találkozás az által is, hogy az elvégzett feladatok eredményének a dokumentálását a hallgatók elektronikus formában készítik el, majd elektronikus formában adják le, végül ebben a formában kapják meg az értékelés eredményét. Ez a megoldás a papírfelhasználás csökkentése érdekében is fontos [3].

A kifejlesztett rendszer a gyakorlatokkal kapcsolatos adminisztratív feladatok elvégzését segíti. Ezek közé tartozik:

- a feladatsorok összeállítása, 
- a hallgatói csoportok kialakítása,

- a beosztások elkészítése,

- a feladatok kiadása,

- a megoldások javítása, ellenőrzése, értékelése.

\section{Az informatikai rendszer}

A gyakorlati oktatást támogató informatikai rendszer az egyik modulja az intézet komplex kiszolgáló rendszerének. A modulnak több kapcsolódási pontja is van a rendszer egyéb elemeivel.

Az órarend kezelő rendszer tartja nyilván az intézet által tartott kurzusokat, a kurzusok óráit (elöadás, illetve gyakorlat), az órák dátumait, az órákat tartó tanárokat. Alapvetően tehát ez határozza meg, hogy mely tantárgyakból lesznek gyakorlatok, milyen tárgyak szerepelnek a gyakorlat kezelő rendszerben. Az órák dátumai a gyakorlatok beosztásának elkészitéséhez szükségesek. Az órát tartó tanárok adatai határozzák meg, hogy a rendszerhez kinek van hozzáférése, hogy melyik tanár látja a gyakorlatok feladatait és ki értékelheti a beadásokat.

Az informatikai rendszer alapja egy relációs adatbázis, és az adatok kezelését lehetővé tevő felhasználói felület. Az adatbázis kezeléséhez PostgreSQL programot használunk, amely egy ingyenes (open-source) termék, emellett számtalan előnye van [4]. Aktívan fejlesztett rendszer, amely igen jelentős közösségi támogatással rendelkezik. Könnyen összekapcsolható más rendszerekkel (pl. web szerver) a felhasználói felület kialakításához. A legnagyobb előnye a kiváló programozhatósága, amely lehetővé teszi a szerver oldali funkciók kialakítását.

A felhasználói felületet egy intézeti belső elérésü web szerver biztosítja, amelyet Apache szoftver felhasználásával alakítottunk ki [5]. Ez egy elterjedt program, amely könnyen telepíthetö Linux alatt (ez az intézeti szerver számítógép operációs rendszere). A hozzáférési jogosultságokat a szerver az adatbázisban tárolt adatok alapján ellenőrzi.

\section{A gyakorlatok előkészítése}

A rendszer használatához különböző adatokat kell bevinni az adatbázisba, hogy a tanárok és a hallgatók el tudják kezdeni vele a munkát [6].

\subsection{Előkészítés a rendszergazdai felületen}

Az előkészítési folyamat első részét a rendszergazda végzi el:

- beviszi az órarendi adatokat a rendszerbe, kialakítja a kurzusokat,

- beállítja a kurzusok előadás és gyakorlati óráit,

- hozzárendeli a tanárokat az órákhoz,

- a tárgyfelvétel alapján hozzárendeli a hallgatókat a kurzushoz.

Ezek a beállítások meghatározzák a hozzáféréssel rendelkezőket. A tanárok ezután kezelhetik a tanári felületet, míg a hallgatók a hallgatói felületen keresztül hozzáférnek a tárgy gyakorlataihoz.

Az órarendben megadott tanárokon kívül más tanárok is hozzárendelhetők a gyakorlatokhoz, pl. a tárgy előadója is kaphat ilyen módon hozzáférést a beadott anyagokhoz és az értékelésekhez. 


\subsection{Előkészítés a tanári felületen}

A tanárok a rendszergazda adatbevitele után megkapják a gyakorlati órák dátumait, valamint a tárgyhoz tartozó hallgatók névsorát. A tanárok az előkészítés során a összeállítják a feladatok listáit, valamint elkészítik a hallgatók beosztását.

\subsubsection{Feladatbank}

A feladatok előkészítése két részből áll. Az első lépés az úgynevezett feladatbank karbantartása. Ebben az adatbázisban lehet tárolni egy olyan feladatkészletet, amelyböl egy adott tárgy feladataihoz majd kiválogathatók a kiadandó feladatok. Újabb félév esetén szükséges lehet a feladatbank frissítése, aktualizálása. A tanár kiválasztja a tantárgyat, majd a tantárgyhoz rendelt feladatok szövegét ellenőrzi, szükség esetén módosítja és elmenti a változtatásokat.

A feladatbank aktualizálása után elvégezhető a feladatok kiválasztása az aktuális félévre. A kiadható feladatok listája egy-egy méréshez tartozik. A rendszerben mérésnek nevezzük a hallgató által egy adott gyakorlat során elvégzendő munkát. A mérésekhez rendelkezésre álló feladatokat egy egyedi azonosítóval látjuk el (pl. sorszám). A rendszerben egy automatizált funkció áll rendelkezésre a feladatok véletlenszerủ sorszámozására. Mivel a feladat sorszámok minden félévben újra generálódnak, így egy adott feladat akkor is új sorszámot kap, ha a feladatbankból több félév során is felhasználjuk. Ez megnehezíti a hallgatók számára a feladatok felismerését, illetve azt, hogy az egymás utáni évfolyamok egymás között kész megoldásokat adjanak át.

\subsubsection{Beosztás}

A tanár következő előkészítő feladata a beosztás elkészítése, amelynek az alapja az úgynevezett méröcsoportok kialakítása. Egyes gyakorlatoknál előfordulhatnak olyan feladatok, amelyeket a hallgatók kisebb csoportokban oldanak meg. Az egy csoportba tartozó hallgatókat mérőcsoportnak nevezzük. Bizonyos gyakorlatoknál előfordulhatnak egyénileg elvégzendő feladatok. Ebben az esetben is méröcsoportokat kell kialakítani, de ezek a "csoportok" egy főből fognak állni. A rendszerben automatizált funkció segíti az egy fös csoportok generálását.

Olyan gyakorlatok is lehetnek, ahol a csoportos mérések és az önálló feladatok egyaránt előfordulnak. Ebben az esetben a hallgatók több mérőcsoportnak is tagjai lehetnek.

A beosztás készítés következő lépése annak meghatározása és az adatbázisba való beírása, hogy az egyes mérőcsoportok melyik órán melyik mérést kell majd elvégezzék. A tanár ezt egy táblázatban írhatja be. A táblázat oszlopai az órák dátumai, míg a táblázat sorai a kialakított mérőcsoportok lesznek. A táblázat mezőiben adhatja meg a tanár, hogy a mérócsoportnak melyik mérést kell teljesítenie.

\subsubsection{Feladat kiadás}

A tanárnak több lehetősége is van a beosztásnak megfelelő mérés során a feladat kiadására. Az egyik lehetőség a rendszer által véletlenszerủen kiválasztott feladat a feladatbankból a méréshez hozzárendelt feladatok közül. Emellett adott feladat azonosító (sorszám) méréshez rendelésére is lehetőség van.

A feladatlista összeállításánál a "választható" tulajdonság is beállítható. Ebben az esetben a hallgatók a hallgatói felületen láthatják a lista feladatait és választhatnak azok közül. Kisebb létszámú csoportoknál ajánlhatja fel a tanár ezt a lehetőséget például olyan esetben, amikor a feladat egy komolyabb tervezési munka, vagy féléves feladat. 


\section{A hallgatói müveletek}

A rendszer felhasználói felületének másik része a hallgatói felület. A szolgáltatások használatához a hallgatóknak regisztrálniuk kell, de csak azok a hallgatók tudnak a mủveletekhez hozzáférni, akiket a rendszergazda hozzárendelt az egyes kurzusokhoz. A felületen megtalálhatók a szokásos bejelentkezési funkciók: regisztráció, jelszó változtatás, elfelejtett jelszó kezelése.

A hallgatói felület a gyakorlatok kezelésén túl a rendszer egyéb elemeihez is biztosítja a hozzáférést, például a szakdolgozat, diplomamunka feladatok kezeléséhez, vagy a záróvizsga modulhoz.

A gyakorlatok támogatásához a hallgatók a következő funkciókat vehetik igénybe:

- hozzáférés a zárt, csak a kurzus hallgatói számára elérhető dokumentumokhoz, segédletekhez, tananyagokhoz,

- feladat választás,

- feladat beadás.

Ha a gyakorlathoz választható feladatok tartoznak, akkor hallgatói felületen megjelenik azoknak a feladatoknak a listája, amelyek még szabadok, még nem választották őket. Erről a listáról a hallgató kattintással jelentkezhet egy feladat megoldására.

A feladatbeadás funkció kiválasztásánál megjelennek mindazok a tantárgyak, amelyek esetében a hallgató tagja egy tanár által kialakított mérőcsoportnak. Ezeknél a tárgyaknál az órák dátumai szerinti sorrendben láthatók az elvégzendő mérések. Ezeknél a méréseknél a hallgató dokumentumokat tölthet fel a rendszerbe, ezt a funkciót nevezzük feladat beadásnak. A feladatbeadás során a rendszer egy új dokumentumot hoz létre a dokumentum kezelö modulban. Ennek a dokumentumnak automatikusan tölti ki a fö adatait:

- a szerző a hallgató lesz,

- a dokumentum címe a mérés címe lesz,

- a dokumentumhoz meta adatok keletkeznek, amelyek alapján azonosítani lehet, hogy a dokumentum melyik méréshez tartozik.

Ezután a dokumentumhoz kapcsolódik a hallgató által feltöltött fájl, amely „rejtett” tulajdonságot kap, így a feltöltés tartalma a dokumentum kezelő rendszer felületén keresztül nem lesz hozzáférhető.

A dokumentumok listáján a hallgató számára megjelenik az értékelés eredménye is, amelyet a tanári felületen rögzítettek.

A rendszer azokat a gyakorlatokat, és a hozzájuk feltöltött dokumentumokat is listázza, amelyeket a hallgató más félévekben teljesített, ezeknél természetesen már nincs lehetöség beadásra.

\section{5. Értékelések}

A gyakorlatok kezelésének utolsó fázisa a beadott megoldások értékelése. A hallgató által elvégzett feladatbeadásról a kurzushoz rendelt tanárok értesítést kapnak, amely tartalmaz egy közvetlen linket, amelyen keresztül a beadás értékelő felület megnyitható. Az értékeléshez a tanár számára ugyanaz a felület áll rendelkezésre, amelyen a beosztást készítette. A beosztás táblázatában a méréseknél a beadások is megjelennek, amelyekre kattintva a tanár megtekintheti és kezelheti az összes dokumentumot, amelyet a méröcsoport (valamely tagja) feltöltött.

A feltöltött fájlok tartalmának ellenörzése után a tanár értékelést kapcsolhat a megoldáshoz. Ehhez igénybe veheti a rendelkezésre álló sablon értékeléseket, például: elkésett, elutasítva, elfogadva, hibás feltöltés, vagy például osztályzatok: 1, 2, 3, 4, 5. Emellett természetesen tetszöleges szöveges értékelést is adhat, ami egy visszajelzés lehet a hallgatónak az esetleges hibákról, problémákról. 
A rendszerhez tartozik még egy értékelés összesítő funkció. Az egyes mérésekhez több beadás is tartozhat, például hibás és újra feltöltött fájlok miatt, vagy esetleg azért mert a hallgató a sikertelen méréséhez pótlás gyanánt egy új feladatot kapott. A rendszer összegyüjti az értékeléseket, majd kiválasztja a mérés végleges eredményét. Végül a hallgató mérési eredményeiből átlagot számol, ami felhasználható a hallgató féléves munkájának értékelése során.

\section{6. Összefoglalás}

A gyakorlatok támogatását ellátó rendszer az egyetemen elérhető oktatás támogató rendszerek mellett, azok kiegészítéseként használható. Az intézet oktatói számára hasznos funkciókkal rendelkezik, amelyeknek az alapja, hogy szorosan integrálódik az intézet informatikai rendszerébe. Összekapcsolódik többek között például az órarend nyilvántartással, a tantárgyi adatbázissal, a dokumentum kezelő modullal.

Nagy előnye, hogy támogatja a gyakorlatok előkészítéséhez és lebonyolításához szükséges adminisztratív folyamatokat, valamint, hogy az intézeti rendszerben visszakereshetővé teszi a feladatokat és a hallgatók megoldásait.

A rendszer használata során eddig (2020/2021/1-es félév) a tanárok 11681 mérési feladatot rögzítettek, amelyekhez a hallgatók 10957 beadást töltöttek fel (itt az eltérés a hallgatói mulasztásokból, a meg nem oldott feladatokból származik). A feltöltött adatmennyiség meghaladja a 9 GB-ot.

\section{Irodalom}

[1] Cennamo, F., Fusco, F., Inverno, M., Masi, A., Ruggiero, A.: A remotely controlled measurement system for education and training of experiments in wind tunnel, Proceedings of the 21st IEEE Instrumentation and Measurement Technology Conference (IEEE Cat. No.04CH37510), Como, 2004, pp. 991-995 Vol.2, https://doi.org/10.1109/IMTC.2004.1351228

[2] Morozov, O., Sadeev, T., Khusainova, G.: Analysis of optical communication systems simulation software for educational purposes, Proceedings Volume 7523, Optical Technologies for Telecommunications 2009; 752302. https://doi.org/10.1117/12.854607

[3] Varga, A. K., Sitku, Á. Gy.: Digitális ZÖLDség a Miskolci Egyetemen, avagy az A4-es pixelek környezetkárositó lábnyoma, Multidiszciplináris Tudományok: a Miskolci Egyetem Közleménye 2020, 10(4):182-194. https://doi.org/10.35925/j.multi.2019.4.15

[4] Asanka, PPG. (2020). Database Design and Modeling with PostgreSQL.

[5] Schiano, W., Waguespack, L., Yates, D.: Apache Web Server, The International Journal of Design Management and Professional Practice 2013, 7(1):1-12. https://doi.org/10.18848/2325-162X/CGP/v07i01/38596

[6] Árgilán, V. S., Kelemen, A.: Interaktív mérőeszközök használatának oktatása tanító alapképzési szakon, XXIX. Nemzetközi Számítástechnika és Oktatás Konferencia, 2019. 